\title{
MENCOBA MENGANALISIS TEORI SOSIOLOGI KLASIK DURKHEIM DI DUSUN X DESA Y KABUPATEN Z PROPINSI O
}

\author{
Oleh: Djaja Hendra*
}

\begin{abstract}
ABSTRAK
Teori Durkheim dalam sosiologi klasik Perancis terkenal dengan tekanannya pada norma-norma kolektif yang mempengaruhi tindakan dan kehidupan individu-individu, tanpa siapa pun yang menyadarinya. Isu-isu kolektif tersebut begitu kuat mengikat, sehingga telah menjadi ciri-ciri khas di dalam hubungan sosial yang bersangkutan. Dari sinilah, kemudian masyarakat itu hidup dalam bermasyarakat maupun bernegara. Teori Durkheim akan dicoba untuk diterapkan di Dusun X, Desa Y, Kabupaten Z, Provinsi O. Hasil-hasil observasi partisipan, terbukti: memang terlihat betapa norma-norma kolektif itu begitu kuat-mengikat individu-individu, sehingga wargapun tidak kuasa secara terang-terangan untuk menolak dari norma-norma yang sudah ditetapkan. Masyarakat Dusun X, tinggal mematuhi dan menerapkan di dalam kehidupan sehari-hari tanpa melihat, apakah norma-norma tersebut sudah sesuai atau tidak dari kehidupan masyarakat yang bersangkutan. Akibatnya, masyarakat Dusun X telah kehilangan kemandirian, jati-diri dan kreativitasnya; atau jika berniat mencoba untuk melawan norma-norma yang telah ditetapan, maka dengan sangat terpaksa siap-siap untuk meninggalkan dusun tempat kelahirannya. Penyebab utama adalah, faktor kemiskinan dikarenakan pekerjaan yang dilakukan sebagian besartukang becak, buruh bangunan dan sawah hanya sebatas untuk makan sampai pada panen berikutnya. Solusinya, memberi pengertian yang mendalam dan intensif kepada tokoh-tokoh masyarakat yang ada di Dusun X.
\end{abstract}

Kata Kunci: Norma Kolektif, Teori Durkhiem, Kehidupan Bermasyarakat, Kemandirian, Kreativitas, Sawah.

\begin{abstract}
Durkheim theory on French classical Sociology is well known with its pressure with the collective norms that affect the action and the life of individuals, without anyone realized it. Those collective issues were tightly bounded, so it has become the special characteristic in the related social relation. From here, then the citizens live in society and in the living state. Durkheim theory will be tried to be applied on $X$ backwoods, $Y$ village, $Z$ province and $O$ province. The result of participants' observation resulted: it is seen that collective norms tightly tied individuals, so that people do not have the right directly to refuse the stated norms. The citizens of X backwoods, obey and apply the norms in the daily live without seeing whether the norm is appropriate for the live of the related people or not. As the result, citizen from X orchardhas lost their independence, self identity and creativity; or if they have a willing to try to break the stated norm, as the result they have to beforced to leave the place where they were born. Themain factor is poverty, it is because the job that are done mostly are pedicab drivers, building
\end{abstract}

${ }^{*}$ Dosen Fakultas Ilmu Sosial dan Politik Universitas Widya Mataram Yogyakarta 
labor and field worker and it is only enough to earn money on food until the next harvest. The solution of this problem is giving a depth and intensive understanding to the prominent figure in $X$ backwoods.

Keywords: Collective Norm, Durkheim Theory, Society Live, Independence, Rice Field.

\section{Pendahuluan}

Sebenarnya, Dusun X dalam Desa Y Kabupaten $\mathrm{Z}$ Provinsi O ini, berbatasan langsung dengan Wilayah Kotamadya M, dengan jarak administratif kurang dari 0.5 $\mathrm{km}^{2}$. Dengan wilayah administratif seperti yang digambarkan, sampai ada orang awam sambil berkelakar, dengan menyebut wilayah-wilayah tersebut telah "terhibriditasi” (Martono, Nanang, 2016: 104); sehingga seolah-olah tidak dapat dibedakan mana yang disebut sebagai kota dan mana yang disebut sebagai desa. Perbedaan-perbedaan wilayah, hanyalah sebatas tiang batasan yang terbuat dari besi tertancap di kedalaman tanah dengan cat warna tertentu mirip warna bangunan-tua yang dilindungi (Unesco) terletak di Provinsi $\mathrm{O}$ (Peneliti tidak mengetahui, apakah dengan warna tertentu tersebut sudah di SK-kan?). Orang-orang di Dusun X Desa Y telah menganggap mereka yang bermukim di Dusun X bagian Utara telah bersifat "kota", sementara orang kota bagianSelatan sendiri juga telah mengganggap wilayah administratif mereka yang saling berhimpit itu dianggap sebagai orang"desa". Perdebatan-perdebatan antarwarga mengenai perbedaan batasan wilayah, tidak akan pernah berakhir, meski tidak munculke permukaan hingga saat tulisan ini dibuat. Entah kalau terjadi di dalam hati dan akan terlibat jika terjadi pertengkaranpertengkaran antarwarga.

Sebenarnya bukan perbedaanperbedaan wilayah administratif demikian yang ingin diungkap, tetapi bagaimana teori sosiologi klasik Durkheim mencoba untuk menganalisis tingkah-laku yang terjadi di Dusun X Desa Y yang berada tidak jauh dari wilayah perbatasan kotamadya. Harusnya wilayah yang saling berdekatan satu sama lain itu, dengan sendirinya dapat saling mengadaptasi (Martono, Nanang, 2016: 13); sehingga yang terjadi kemudian disebut sebagai wilayah "campuran", atau disebut sebagai wilayah desa bukan maupun sebagai wilayah kota juga bukan. Bisa saja terjadi orang Desa Y bergaya seperti orang kotaatau orang Desa Y atau Dusun X bergaya seperti orang kota. Walau, nampaknya gaya seperti itu tidak menjamin, mengingat orang 
yang bermukim di Dusun X kelihatan sekali desanya, terlihat mulai dari sikap-sikap,status pekerjaan, maupun cara berpakaian dan berdandan. Wilayah-wilayah seperti ini oleh para pakar, yang lazim dalam membahas masalah-masalah interaksi wilayah desa-kota (Kompas.com, Rabu 29/3/2017), mereka dapat dikatakan sebagai wilayah abu-abu. Walaupun dalam kasus terakhir ini, tidak terjadi. Orang desa tetap saja bergaya sebagai orang desa. Orang kota tetap saja bergaya sebagai orang kota.

Wilayah "campuran" atau abu-abu ini, angka kriminalnya sangat tinggi (seputar ring-road Provinsi O). Para sosiolog sering menyebut wilayah administratif semacam ini dikenal sebagai "zombie area" (www.casageek.com.br Akses, 19 Agustus 2019). Bagi orang-orang yang tidak pernah menyaksikan film zombi, zombi itu samalah artinya dengan 'mayathidup' (Bahasa Inggris = orang bodoh). Sebagai kasus, kira-kira setahun silam wilayah semacam ini pernah menjadi sarang penjahat maupun pembegal. Mereka dikenal dengan istilah (Bahasa Jawa = orang yang berdarah-darah). Sering orang yangmengetahui wilayah-wilayah seperti ini jauhlebih waspada dan tidak berani berjalan sendirian di malam hari, apalagi tanpalampu penerangan jalan. Bagi mereka yang jauh tempat-tinggal terpaksa harus kos/kontrak dekat tempat-kerja. Keesokan hari baru kembali ke rumah, atau seminggu sekali baru kembali ke rumah. Begitu seterusnya. Oleh karena itu, dalam kasus ini, kecil kemungkinan ada penjahat yang akan berbuat kriminal di pusat-pusat kota dan perbelanjaan misalnya; atau pusat-pusat bisnis atau pusat-pusat pemerintahan lainnya. Kecuali pencopet.

Dengan kehidupan semacam itulah Dusun X di Desa Y itu terbentuk. Dia dekat wilayah kota. Sebagaimana dikatakan, wilayahnya seolah-olah menyatu dengan kota. Tetapi komplek-sitas permasalahannya sangat tinggi. Padahal di Dusun X hampir ada empat perguruan tinggi (satunya belum dibangun, sudah tentu membawa normanorma dan nilai-nilai kekotaan serta inovasiinovasi baru), mestinya mereka sudah melek informasi. Menghargai pendidikan. Dengan demikian, mereka mestinya telah terbukadan siap menerima pendapat-pendapat yang berbeda. Mereka mengetahui tentang perkembangan dan berbagai permasalahan kota di Provinsi O, termasuk kota-kota besar lain di Indonesia bahkan mancanegara (Malaysia, Singapura dan Hongkong), tetapi tidak untuk negara-negara lain. Mengapa hal demikian dapat terjadi di Dusun X Desa Y Kabupaten Z, Provinsi O? Pertanyaan 
demikian sengaja dilontarkan denganharapan untuk dapat menggali lebih dalam tentang apa-apa yang sedang terjadi di Dusun $\mathrm{X}$ tersebut.

\section{Solidaritas Sebagai Hal Terpenting}

\section{Dalam Kehidupan Kelompok-Kelompok}

Sosial

Mungkin teori sosiologi klasik

Durkheim yang mirip dengan teoristrukturalfungsional Talcott Parsons ini, sudah lama ditinggalkan para pemikir (Ritzer, 2012: 129), karena selain telah usang juga tidak terlalu tajam lagi untuk dipergunakan sebagai pisau analisis. Jika dahulu teori-teori semacam ini begitu populer dan terkenal, untuk mengulas masalah-masalah sosial di negara-negara Eropa dan AS. Prostitusi jalanan, pencurian, korupsi, maryuana, pengemis, gelandangan, anak-anak nakal dan telantar, orang jompo, penggelapan, perselingkuhan dan lain sebagainya, khas negara-negara maju; di masa itu, kemudian, ada yang mempergunakan untuk angkatan bersenjata di suatu negara, bahkan sisa-sisa di masa lalu itu dimanfaatkan untuk menghapus/menghindari dari jejak rasa malu, karena kalah dalam peperangan maka diciptakanlah film "Rambo" itu. Di dalam film tersebut dibuat mereka yang menang dalam peperangan. Kasusnya, seolah-olah diambil dari alam Vietnam Selatan sekitar tahun 1970-an, di mana seorang manusia super berbadan besar secara sendirian tetapi serba-bisa termasuk menggunakan peralatan persenjataan apa adanya untuk membunuh dengan melawan orang-orang Vietnam lain yang banyak itu. Dan menurut cerita, mereka yang banyak itu bisa dikalahkan oleh seorang manusia super tadi. Negara Vietnam yang diceritakan, ternyata masih utuh tetap berdiri hingga sekarang dan masihtetap utuh sebagai penganut ideologi komunis. Film tersebut, mungkin masih sempat kita saksikan, tetapi bagaimana kita menggunakan teori-teori strukturalfungsional yang ternyata kalah melawan teori-teori rasional Weberian.

Bagi sementara orang yang ketagihan menyaksikan film-film perang, hanya dianggap sebagai hiburan belaka atau pelepas kepenatan sehabis bekerja. Mereka tahunya, yaitu sedang menyaksikan film- film, mereka yang berbuat jahat di awal cerita, berakhir, akan mengalami kekalahan. Awalnya, kebenaran itu akan terseok-seok, akhirnya mereka akan memperolehkemenangan, dan film pun berakhir dengan happy ending. Penonton pun bersorak-sorai dan bertepuktangan. Begitu seterusnya. Bagi analis sosial tidak demikian. Film-film 
yang disaksikan itu dicermati, dikupas dan dikaitkan dengan realitas serta teori-teori apa yang melatar-belakangi. Perdebatanperdebatan teoritis pun dimulai, sampai kepada peran negara, mengapa film-film tersebut diimpor. Untuk mencerdaskan bangsanya kah, atau sekadar memenuhikuota karena sudah terlanjur menandatangi perjanjian bilateral dua negara; atau para sineas kita yang lagi tidak produktif untuk menghasilkan karya-karya gemilang. Dan seterusnya, dan seterusnya.

Film pada hakekatnya adalah sebentuk potret kecil dari sketsa kehidupan manusia/realitas sosial yang sesungguhnya. Sebenarnya, dari film pulalah dapat diketahui baik-buruk sifat dan tingkah-laku seseorang atau suatu negara (bukan ditinjau secara politik). Menurut kacamata Durkheim (Ritzer dan Barry Smart, 2012: 153), setelah melihat bahwa dalam sosok film tersebut, yang dipentingkan dan diutamakan adalah adanya kesatuan dan persatuan dalam kelompok-kelompok sosial. Mungkin, di dalam kelompok-kelompok sosial dapat terjadi, ada orang yang beraneka sifat, tabiat dan warna, seperti misalnya: bentuk rambut, aroma tubuh, rupa wajah, bentuk mata, perawakan hingga etnis dll; semua dari mereka tergabung, dalam apa yang disebut sebagai karakter-karakter etnis (Scott, John,
2012: 51) yang “disamakan”. Penyamaan ini kemudian berubah menjadi karakter bangsa yang kita harapkan atau inginkan. Mereka ini adalah ide-ide yang mendorong tindakan dan medefinisikan 'kararter' kebangsaan dari sebuah populasi. Tanpa karakter bangsa, negara dapat limbung hingga memudahkan negara-negara asing buatmengintervensi dan menganeksasi, untuk kemudian dapat berbuat apa saja terhadap negara-negara yang dianeksasi.

Walaupun, kemungkinan itu kecil terjadi sekarang-sekarang ini. Bisa dihujat oleh seluruh negara/bangsa di dunia. Paling banter menjajah dalam bentuk ekonomi dan sosial. Seperti: pemberian hutang oleh bank dunia, IMF, negara-negara pemberi hutang lain dengan bunga tinggi, tenaga-kerja dapat memasuki negara lain tanpa keterampilan memadai, menempatkan kantor Unesco dan pengungsi di suatu negara, dan lain-lain. Di sinilah, mereka disatukan dalam kelompokkelompok sosial yang sama. Meminjam film tadi, mereka sebagai tentara, mereka berjuang untuk menunjukkan dominasi, jatidiri, dan berjuang untuk membela negaranya. Walaupun, agak sulit logika kita dapat menerima secara sempurna manakala negara yang satu dapat menganeksasinegaranegara lain, apa pun alasannya. Kumpulan kelompok-kelompok sosial ini 
oleh Durkheim disebut sebagai solidaritas sosial (Martono, Nanang, 2016: 51). Tanpa memandang suku, ras, agama dan lain sebagainya; terpenting, mereka bersatudalam satu wadah/himpunan di dalam satu negara bangsa.

Benarkah tindakan mereka berkumpul dan disamakan dalam satu korps ketentaraan dalam membela republik/negara yang dicintai? Pertanyaan moralis seperti itu, sudah tentu tak perlu dijawab mengenai benar-tidaknya. Dipentingkan adalah, adanya kesatuan dan persatuan, dalam bahasa lain disebut sebagai korps tadi. Jadi, solidaritas adalah sebentuk kekuatan yang mengikat orang perorangan yang ada di dalamnya. Dalam ketentaraan sebagaimana disebutkan, mereka bersatu sebagai sebuah kekuatan yang tiada bandingnya. Kekuatan tersebut semakin kuat mengikat apalagi dibekali dengan pakaian uniform beserta emblem yang tersemat di dada, senjata organik berada di pinggang, sepatu bot ada di kaki dan lain sebagainya; tentu membentuk solidaritas tersendiri yang membedakan kelompoknya dengan kelompok-kelompok sosial yang lain, tentu luar biasa kuatnya. Dengan korps atau solidaritas semacam ini diharapkan orang lain tidak ada yang berani "mengganggu". Di lingkungan mahasiswa, pemakaian jaket almamater, kaos yang seragam, Aparatur Sipil Negara (ASN), satpam adalah sebagian di antaranya.

Itulah sebabnya, peristiwa yang terjadi di salah satu penjara di Indonesia sekitar 6 tahunan yang lalu, sempat mengegerkan khasanah publik; di mana sekompi tentara dalam satu tangsi militer bergerak bersama menyerbu suatu kota (padahal tempatnya cukup jauh dan berada di provinsi lain) mereka sampai sempat menyerang penjara di Provinsi O. Sebab, bekas pimpinan mereka (sebelum mereka ditangsikan) terbunuh oleh preman-preman di sebuah kafe di Provinsi O. Begitu mendengar, jika bekas pimpinan mereka tewas mengenaskan, bekas anak-buah anakbuah pimpinan mereka tersebut, tersentak kaget. Mereka mungkin berpikir dan resikoresiko yang bakal mereka diterima. Tetapi logika dan perasaan yang terjadi sudah sedemikian rupa, tuntutan balasan lah sebagai jawaban atas kematian bekas pimpinan (militer) mereka dahulu semasa bertugas. Terbukti kemudian, tuntutan balasan itupun jadi dilakukan, para anakbuah tersebut siap untuk menanggung sanksi yang diberikan, termasuk pemenjaraan dan pemecatan dari militer aktif. Premanpreman yang sempat di penjara karena perbuatannya, langsung dihabisi dengan 
senjata otomatis. Kita tidak ingin mengetahui siapa yang benar maupun salah dalam persoalan ini. Justifikasi semacam itu tidak perlu dilakukan dalam konteks akademis kita. Terpenting dari itu semua, adalah semangat korps tadi. Meskipun dengan segala kepasrahan anak buah tadi, kini, setelah mereka menuntut balas, mereka puas dan selanjutnya menempuh hidup masing-masing. Semangat korps tidak akan pernah hilang/padam. Walaupun mereka sudah tidak mengabdi lagi kepada republik tercinta tetapi semangat masih tetap bergelora dan menyala-nyala.

Peristiwa dalam film "Rambo" yang sempat ditayangkan ketika mereka menyerbu Vietnam beberapa dekade silam, sempat menang perang? Tidak. Sejarah pun membuktikan negara penyerbu tidak memenangkan peperangan itu. Bahkan, dengan peralatan yang secanggih itu dapat dilumat habis dengan hanya perlengkapan seadanya oleh lawan. Itulah semangat solidaritas yang dibangun Durkheim di dunia ketentaraan. Walaupun kini, telah banyak terjadi perubahan di sana-sini di dunia ketentaraan kita, seperti adanya dunia inteligen, peralatan ketentaraan yang semakin canggih, seragam makin bervariasi dll, semangat solidaritas tetapdipertahankan. Mungkin Dusun X Desa Y tidaklah hendak meniru semangat semacam itu, mungkin mereka tidak menyaksikan sendiri film tersebut, tetapi tingkah-laku mereka nampaknya mengarah ke arah itu. Walaupun mereka dekat dengan kota tidak berarti segala sesuatunya mengikuti kota begitu saja.

Dalam dunia akademis, solidaritas yang dikemukakan tersebut berkembang menjadi solidaritas mekanik dan solidaritas organik (Martono, Nanang, 2016: 51). Untuk menggambarkan dinamika perubahan masyarakat atau kelompok-kelompok sosial tadi ke arah yang semaunya sendiri. Lazimnya, solidaritas mekanik disebut sebagai masyarakat desa dan solidaritas organis sebagai masyarakat kota. Jika dalam solidaritas mekanik bahwa setiap orangdapat berbuat apa pun maka dengan cepat dapat diketahui perbuatan-perbuatan yang dilakukannya. Tidak demikian dengan solidaritas organis. Bentuk tembok rumah yang tinggi, pagar rumah yang selalu tertutup dan menjulang, jarak rumah ke jalan umum begitu jauh sehingga membutuhkan bel/alarm jika hendak berkunjung ke rumah yang bersangkutan, belum lagi memelihara anjing dll tentu dapat menyulitkan kitasemua. Orang menjadi enggan untuk bertamu, apalagi perilaku tuan rumah penuh dengan kecurigaan, tidak menyukai tamu 
dst, dstnya; sehingga dalam kacamata solidaritas organis atau masyarakat yang terbuka semacam itu, semakin menyulitkan orang lain untuk sekadar melihat ke dalam isi rumah yang bersangkutan, mengenai apa yang sedang diperbuat oleh penghuni rumah.

\section{Solidaritas Mekanik di Tengah Perkotaan}

Sebagaimana dikatakan di atas, bahwa lokasi Dusun $\mathrm{X}$ ini tidak berjauhan dengan perkotaan di Provinsi O, seyogyanyatingkahlaku, sikap-sikap dan perbuatan mengadaptasi nilai-nilai dan norma-norma kota; sehingga dapat menjadikannya suatu wilayah sebagai wilayah abu-abu, yaitutidak diketahui lagi mana bentuk-bentuk orisinalnya. Harusnya, masyarakat menbentuk perilaku-perilaku dan sikapsikap yang baru sama sekali, yang berbeda dan memben-tuk tingkah-laku tingkah-laku tersendiri. Tetapi nampaknya hal tersebut, makin menguatkan solidaritas mekanik yang ada. Jika sosiolog klasik Durkheim masih hidup, agak terheran-heran dia melihat perilaku masyarakat dapat berbuat seperti itu. Jika ada informasi dari luar dusun, tetap saja mereka terima tetapi dimodifikasi (kesan-kesan) oleh penduduknya menjadi bentuk perilaku baru di dusunnya. Bentukbentuk perilaku baru tersebut sebagai wujud dari perpaduan antara nilai atau norma- norma lama dengan nilai atau norma-norma baru, yang dipergunakan sebagai suatu kekhasan Dusun X. Mungkin secara agama hal itu dilarang tetapi secara budaya, tidak. Seperti, menjual telor asin di suatu pantai tertentu pada setiap Selasa Kliwon danJumat Kliwon, berdekatan dengan cungkup kuburan orang yang disucikan di pantai itu. Pulang ke rumah hingga pagi menyingsing. Menurut mereka, keberkahan dari Tuhan Yang Maha Esa turun justru pada hari-hari tersebut [Kirakira hampir sama denganwisata religi yang dilakukan di Gunung Kemukus (jalan antara Solo-Purwodadi). Kalau ingin kaya (harta), dalam keluarga yang bersangkutan maka suami-istri dari keluarga itu harus mencari pasangan lain yang bukan istri atau suami dari keluargatersebut di Gunung Kemukus ini. Waktunya, antara pukul 08.00 malam hingga esok harinya. Setelah menemukan pasangan lain itu, kemudian mereka memadu-kasih di sela-sela akar pohon yang kebetulan sangat rindang dan gelap sekali hingga ke kuburan seorang Pangeran (dari Jawa) yang berada dipuncak Bukit (disebut gunung) Kemukus (tinggi gunung sekitar 25 meter), di mana kuburan tersebut dipasangkan kelambu (banyak sekali bekas bakaran lilin dan kemenyan di sekitar kuburan). 
Suami-istri yang telah menemukan pasangan lain itu katalah bertemu di Gunung Kemukus itu, Hari Selasa-Kliwon. Untuk selanjutnya, selama 7 kali berturut-turut, si suami atau si istri tadi harus menemukan pasangan lain lagi (bukan orang yang sama) selama Selasa Kliwon berikutnya. Jadi kirakira hampir 3 bulan lamanya. Menuruttradisi orang yang mempercayai, tidak lama setelah memadu-kasih dengan orang lain yang bukan pasangannya, berangsur-angsur keluarga tersebut akan memperoleh kekayaan --walau kini, sebagian Gunung Kemukus telah tenggelam --- ingat, Kedung Ombo ada di masa Presiden Soeharto --- wisata religi ini masih tetap dipertahankan dan dilakukan orang, meskipun sudah dirusak oleh laki-laki hidung belang atau wanita jalang sebagai lokasi pelacuran terselubung. Jadi harus hatihati dan pandai- pandai membedakannya].

Selanjutnya, dalam bentuk penyimpangan sosial lain misalnya. Apakah sekitar seabad lalu kita sering mendengar adanya kasus perkosaan? Jawabnya, hampir pasti tidak! Mungkin juga di masa itu tidak dikenal. Jika kita melihat tayangan wayang sebagai prototipe masa lalu, apakah kita ada mendengar kasus-kasus yang disebutkan? Mungkin, tayangan wayang banyak menceritakan aib seseorang, perebutan tahta kerajaan, perkelahian dan perselingkuhan serta goro-goro (Pandawa Lima) hampir pasti tidak, bukan. Paling tidak wayang bercerita tentang apa yang terjadi di masa lalu dan masa kini, tidak lebih. Cerita semalam suntuk, hanya seputar itu. oleh karena itu, perkosaan yang terjadi di sebelah daerah kuburan malam hari di Dusun $X$ yang dilakukan oleh pemuda-pemuda dusun dan dusun tetangga, sungguh sesuatu yang memprihatin-kan, menyedihkan, dan memalukan. Bagaimana mungkin, polisipolisi yang menangkap satu persatu pemudapemuda dusun yang melakukan tindakan tercela dipertontonkan dihadapan orangorang? Bukankah, tindakan tersebut merupakan hasil tayangan atau tontonan di dunia modern sekarang. Informasi yangcepat dan langsung diterima dimodifikasi sedemikian rupa maka jadilah seperti tindakan tersebut. Lucunya, sebagai penangkis untuk menutupi rasa malu, yang disalahkan justru perempuan itu. Sulit sekali logika kita dapat berjalan sempurna. Mirip dalam sosiologi deviansi, apa yang disebut sebagai politik netralisasi. Orang lain dianggap bersalah. Begitu seterusnya. Seperti mencoret-coret dinding rumah orang, dianggap dia seagai orang yang sedang melukis. Sekiranya polisi menangkap mereka karena berbuat asusila, 
justru polisi-polisi yang dianggap bersalah karena telah mengganggu kesenangan mereka, mereka tidak sedang memperkosa.

Demikian pula dari sisi akademis yang lain. Ada seorang warga dari Dusun X sedang bersekolah di perguruan tinggi (kebetulan PTN). Bukan PTN/PTS yang dipersoalkan di sini. Tetapi dia adalah warga penduduk Dusun $\mathrm{X}$ yang sampai ke jenjang pendidikan tinggi (sekarang ada 1 lagi, di PTN). Dengan alasan bahwa keluarga bersarnya meminta dia untuk bersekolah di Bandung dengan sangat terpaksa dia bersekolah di sana. Menggantikan pendidikan tinggi yang diperolahnya dengan mengikuti skuadron angkatan udara, meski pangkatnya setingkat SMA tetapi dia langsung bekerja dibandingkan dengantamat perguruan tinggi, masih harus mencari pekerjaan. Belum tentu dapat di masa seperti sekarang ini. Hingga kini, orang tersebut sudah lebih dari 12 tahun tidak pernah kembali ke dusun. Tetapi hakekatnya, dia adalah orang pertama yang bersekolah di perguruan tinggi, sehingga memungkinkan dia dicemooh dan dicaci oleh masyarakat sekitar. Nampaknya, keluarga besarnya menyadari akan hal itu, kemudian mengungsikannya ke luar dari Dusun X. Kelihatannya, keluarga besarnya bertemu dengan saudaranya atau yang bersangkutan di luar provinsi ini. Berbeda dengan seorang lagi yang sekarang sedang menempuh pendidikan di perguruan tinggi yang sama. Mungkin karena jenis kelaminnya perempuan saja, tekanan penduduk Dusun X tidak terlalu berat. Di samping keluarga besar perempuan itu tidak-terlalu menghiraukan.

Selebihnya, tidak ada yang bersekolah di perguruan tinggi. Paling tinggi hanya mengenyam pendidikan tingkat SMA/SMK, setelah itu pergi ke luar negeri menjadi TKW/TKI atau nganggur atau membantu orangtuanya di rumah atau ke kota besar lain menjadi buruh kasar atau asisten rumah tangga. Meskipun isu terakhir ini sebagai pilihan terakhir daripada tidak bekerja sama sekali. Di Dusun X tersebutada seorang anak yang hanya bersekolah sampai tingkat SD saja. Itu pun ditempuh dengan susah payah. Di SD tersebut ditempuhnya hampir 10 tahun. Setiap tingkat di SD tidak naik kelas dan hampir setiap tingkat ditempuh dalam 2 tahun. Pernah ada seorang sukarelawan berniat untuk membantu menyekolahkannya, setelah mendengar bahwa oleh orangtua siswa mau meneruskan ke jenjang SMP, tidak jadi diteruskan. Anaknya sendiri yang tidak berniat untuk bersekolah lagi. Dia lebih suka, selain membantu kegiatan 
rumah-tangga seperti membantu keluarganya menyapu lantai dan mencucipiring; juga membantu orangtuanya dalam berdagang/warung makan. Setelah mendengar realitasnya seperti itu, sukarelawan tadi kemudian mengurungkan niatnya untuk menyekolahkan anak yang bersangkutan. Sekarang sudah lebih dari 5 tahunan tidak bersekolah. Tinggal menunggu ada orang lain yang mempersuntingnya.

Umumnya, anak-anak di Dusun $\mathrm{X}$ tidak mau melanjutkan pendidikan ke sekolah yang lebih tinggi. Cukup sampai SLTA saja. Kita mungkin akan kaget, setelah lulus dari SLTA tersebut, anak itu sekitar (6) bulan kemudian tahu-tahu sudah menikah atau ke luar negeri. Bahkan mungkin tanpa melakukan pendekatan-

pendekatan terlebih dahulu. Kita mengetahui, setelah beberapa bulan kemudian anak tesebut telah mempunyai anak. Sementara bagi yang tidak mengalami perjodohan (melalui pendekatan/pacaran, langsung menikah). Belum lagi anak-anak sudah hamil dahulu baru kemudian dinikahkan. Ada dengan suami/istri atau orang yang pernah dekat/pacarnya atau sama sekali dengan orang lain yang tidak dikenal. Bisa dibayangkan seorang anak yang layaknya bersekolah, tahu-tahu sudah menikah. Bagi mereka yang laki-laki, menggarap sawah orangtua atau mertua; sementara bagi mereka yang perempuan jadi ibu rumah tangga membantu orangtua atau mertuanya.

Sementara bagi mereka yang bekerja di sektor formal atau informal, bila ada kesempatan, melakukan korupsi atau bila perlu menggadaikan sawah orangtua tanpa sepengetahuan orangtuanya. Jika berlamalama, orangtuanya tidak merasa kehilangan sertifikat, dapat saja sawah (tanah) tersebut hilang karena rentenir. Pernah ada kejadian, orangtuanya sampai jatuh miskin, dari sebelumnya yang memang sudah miskin. 'Sudah jatuh tertimpa tangga'. Jika mungkin masih bisa disusul keberadaan sawah tersebut, mungkin masih dapat ditebus. Walau kita mengetahui juga agak sulit ditebus, mengingat uang untuk menebusnya lipat beberapa kali. Bisa dibayangkan biaya penebusannya kalau jatuh kepada rentenir. Bank minded tidak terlalu akrab di telinga. Demikian pula, ada seseorang di Dusun $X$ yang bekerja di sektor formal dan melakukan penggelapan. Hanya dengan belas kasihan dari pimpinannya saja dia tidak langsung diberhentikan atau ditahan. Potong gaji bulanan hingga uang yangdigelapkan dapat dikembalikan. Mungkin dia dapat bertahan hidup dikarenakan dia 
masih memiliki sawah tinggalan orangtuanya. Tetapi selama sekian tahun sawahnya hanya cukup untuk makan. Begitu seterusnya.

\section{Kemiskinan Penyebab Terjadinya Solidaritas}

Sungguh, sangat banyak kasus yang terjadi di Dusun X. Dengan tanpa harus menceritakan lebih lanjut setiap persoalan, dari hasil observasi ditemukan antara lain: ada di antara mereka yang mampu membuat rumah kos/kontrakkan, pemutusan listrik karena tiga bulan tidak membayar,meminjam uang sesama tetangga tetapi tidak sanggup untuk mengembalikan, dengan jaminan sawah (tentu dengan harga murah), menjadi tukang gojek, menjadi penjaga toko kelontong atau penjaga toko konter HP milik orang lain, ada pendidikan Paud di dusun tetapi bersekolah Paud di dusun lain padahal jauh lebih mahal, mantan dukuh tidak memberikan contoh yang baik, ada pensiunan polisi, ada yang 'kumpul kebo', nikah siri. Menitipkan makanan ke angkringan, membawa ruyung (sejenis tombak) untuk jaga diri saat gempawalaupun siapa yang mau mencuri karena sama-sama miskin, ada perumahan (sekitar 10 rumah) dan berniat menjual rumah kembali, banyak warung makan dan kelontong hanya sebagai penjaga belaka, ada yang memiliki warung tetapi tidak profesional kemudian macet alias bangkrut, luas tanah yang dimiliki dapat bergeser, dst semua itu baik-baik saja. Terkesan tidak ada masaah.

Semua itu dilakukan, bisa jadi dikarenakan mereka itu miskin (walau ada di antaranya tidak mengakui). Kemiskinan yang mendera memungkinkan mereka tidak dapat berbuat apa pun. Betul, mereka masih memiliki sawah dan sedikit ladang, sehingga tidak memungkinkan mereka mempunyai uang lebih atau bisa jadi mereka akan jatuh ke lembah kesengsaraan. Dengan sawah dan ladang sebenarnya cukup untuk sampai kepada panen berikutnya. Dengan harapan panennya berjalan lancar dan cuaca begitu mendukung. Jika, diserang hama wereng, hama tikus dan belalang menyebabkan mereka terlilit hutang atau tidak mengembalikan hutang-hutang (BahasaJawa = ngemplang) mereka. Jika panen tiba,hanya untuk membayar hutang memungkinkan mereka gali lobang tutup lubang. Akibatnya, mereka jatuh ke dalam kemiskinan. Itu kalau panen gagal pada musim itu. Tetapi kalau mereka gagal panen dua-tiga kali dalam musim-musim yang ada,apakah mereka tidak tambah terperosoksemakin dalam. Membuat anak-anaknya 
tidak dapat bersekolah tinggi. Menjual sawah yang dimiliki, itu solusinya. Selain anak-anak tidak sekolah, juga akhirnya mereka dapat menjadi buruh pada orangorang di dusun yang sedikit-banyak dianggap mampu tadi. Tetapi sampai kapan?

Menjadi asisten rumah tangga bagi ibu-ibu rumah tangga kepada orang-orang yang sedikit mampu hanya untuk makan gratis hingga malam hari. Sampai kapan orang-orang yang sedikit mampu tersebut dapat bertahan lama, kecuali dengan mengurangi gaji (kalau bergaji) mereka, tetapi dapat makan sesuap nasi dari majikannya. Walaupun, kita lihat bekerjanya serabutan. Dalam observasi-partisipan, nampaknya memang cara demikian yang dilakukan atau kerja di pabrik-pabrikmenjadi buruh kasar terhadap mereka yang memasuki usia produktif. Hasil dari ladang dan sawah kebanyakkan tidak mencukupi alias kekurangan; sehingga tidak mungkinmereka dapat bergerak ke sana kemari dengan pendapatan yang sesedikit itu. Dengan kondisi-kondisi keluarga semacam itulah sebagai penyebabnya. Kehilangan rasa percaya diri, diikuti dengan bisikan- bisikan dari lingkungan sekitar memungkinkan mereka tidak dapat berpikir alternatif untuk mencari pekerjaan tambahan. Setiap lembaga-lembaga yang hadir dan diikuti di Dusun $X$ hampir semuanya tidak menghasilkan uang tunai.

\section{Kesimpulan}

Meski Dusun X Desa Y dekat sekali dengan kota sehingga bisa disebut sebagai wilayah desa-kota, tidak berarti bahwa mereka dapat tercerabut dari akar budayanya. Nampaknya, upaya-upaya itu tetap mereka pertahankan, bahkan, jika mungkin, menciptakan bentukbentuk budaya baru yang tidak ada sama sekali di kota atau di dusun. Bentuk-bentuk atau norma-norma baru, umumnya digali dari kehidupan sehari-hari atau agama keseharian (bukan dari Al-Quran danhadist). Akibatnya, bisa saja tidak sesuai bahkan bertentangan dengan Al-Quran dan Hadist. Misalnya: sedekah kubur, yaitu dengan membersihkan rumah-rumah kuburan yang terbuat dari kayu jati ditutupi genteng itu dihilangkan (bentuknya dahulu seperti pendopo), sekarang mirip taman makam pahlawan, tanpa bangunan-polos saja. Sementara seseorang yang dianggap pendiri dusun tetap dipertahankan tegak berdiri. Sekarang, mulai ada kerja-bakti yang dilakukan khusus untuk ibu-ibu rumah tangga dan remaja putri. Dilakukan pada hari ahad dimulai di bulan pertama setiap bulan, mulai pagi sekitar pukul 06.00 hinggapukul 12.00 siang. Sungguh merepotkan. 
Bisa dibayangkan ibu-ibu rumah tangga dan remaja putri dengan membawa skop, pacul, gerobak dorong, sapu lidi dan alat kerjabakti lainnya. Untuk mereka yang laki-laki dan pemuda, dilakukan pada hari ahad bulan kedua dan jika musim hujan bisa dilakukan setiap ahad. Bagi yang tidak ikut kerja-bakti maka 1 sak semen harus disiapkan dan tidak boleh berturut-turut. Bagaimana dengan mereka yang mengajar di universitas terbuka (hanya kuliahnya Sabtu dan Minggu) atau mereka aplusan di pabrik-pabrik hari ahad atau menjadi Satpam dalam suatu kantor di hari ahad.

Dalam sosiologi pembangunansikapsikap dan tingkah-laku semacam itubagusbagus saja. Artinya, dapat sajamemperlancar kegiatan-kegiatan. Pastinya, pembangunan yang dicita-citakan di Dusun $\mathrm{X}$ akan sangat cepat mencapai tujuan-tujuan yang diinginkan. Sebagaimana kita lihat dalam Musrembangdes (diminta oleh desa) setiap usulan-usulan dari dusun akan sangat mudah direalisasikan oleh pihak desa. Hanya persoalannya, pembangunan yang ada di Dusun $\mathrm{X}$ sebatas artifisial bangunan fisik belaka. Pendirian gapura sebagai penunjuk arah ke dusun yang bersangkutan (padahal dekat kota dan semua orang sudah mengetahui arah dusun), pendirian tugu selamat datang, pembangunan parit/got tempat buangan limbah keluarga dan air hujan hanya dinikmati orang tertentu saja, jalan kecil atau gang di dalam dusun di konblok, lampu jalan pada gang-gang dialiri arus listrik langsung dari PLN, dusun ini tidak pernah mau menerima mahasiswaKKN dan seterusnya; sementara yang bersifat nonfisik tidak mudah untuk direalisasikan. Koperasi saja misalnya, tidak bisa berjalan baik dan akhirnya mati suri,Posyandu balita dan orangtua merupakan program pemerintah dalam menambah gizi tetapi hanya penimbangan balita saja yang berjalan, sementara orangtua-orangtuamerasa gizinya sudah cukup sehingga tidak perlu datang ke Posyandu atau orangtua- orangtua diberi kesehatan jasmani, jawabnya, kerja di sawah kan olahraga juga, jadi untuk apa gerakangerakan jasmanidilakukan.

Kegagalan demi kegagalan sudah menjadi bagian dari kehidupan di Dusun X. Program-program pemerintah agak tersendat-sendat jalannya. Kreativitas yang muncul dari warga sebatas figuratif belaka dan memang yang demikian itulah yang terlihat dan lebih mudah dibicarakan dibanding dengan yang tidak kelihatan. Kuatnya isu-isu bersama (kolektif) ini memungkinkan orang lain tidak berani menolaknya. Dengan kehadiran seorang 
purnawirawan polisi pun, ternyata bergeming, malah dia harus larut didalamnya serta tidak berani membenarkanatau menolak secara terang-terangan. Mungkin sebagian orang-orang Dusun $\mathrm{X}$ ini, mirip dengan seorang purnawirawan polisi itu, tidak berani juga untuk menyatakan sesuatu secara langsung mengenai ketidak- bolehan, tetapi kabar-kabur yang dihembuskan antartetangga, lama-lama dapat juga tersebar ke seluruh dusun, akibatnya, secara kolektif mereka akan melakukan tindakan-tindakan di luar norma. Jadi, tidak dilihat benar-salah setiap orang yang ada di dusun, mengikuti atau tidak norma-norma yang sudah dibangun. Penanaman di sawah-sawah penduduk, tidakboleh ada yang bertentangan dengan himbauan tokoh-tokoh masyarakat setempat.Dengan alasan hama wereng maka akan mengikuti himbauan-himbauan yang sudah disepakati. Betul, sawah dan mungkin juga ladang milik kita; juga ada programprogram dari pemerintah (desa). Tetapi tidak dengan sendirinya kita dapat berbuat sesuka hati.

Kita mengikuti himbauan pemerintah untuk menanam sesuatu tetapi tanaman tersebut bertentangan dengan tanamaman dari dusun, jika muncul hama tikusmisalnya. Tanpa musyawarah, kita langsung disalahkan. Meski mungkin tidak sesuai lagi dengan musim-musim yang terjadi masa itu. Sawah ditatami palawija dan tumpang sari tatkala musim hujan serta tanaman padi membutuhkan air berlimpah maka tetap saja dilakukan penanaman di musim kemarau. Padahal periuk nasi harus ngebul tetapi bila bertentangan dengan himbauan tadi maka meski seseorang di dalam keluarga kekurangan beras, tetap tidak akan memungkinkan menanam padi. Demikian pula dengan masjid. Corong himbauan untuk sholat pun keras sekali, sehingga mungkin dapat mengganggu orang sekitar, tetapi tidak-dirasakan/tidak-didengar. Padahal, meski sudah dihimbau untuk datang sholat, hampir tidak ada orang yang sholat. Dia menjadi muazin, dia menjadi imam dan dia pula lah yang menjadi makmumnya.

Nampaknya, kita ingin melihat ikatan macam apa yang sesungguhnya terjadi di Dusun X. Hasil observasipartisipan menunjukkan kepada kita, adanyakey person atau dengan melihat tokoh-tokoh masyarakat Dusun $\mathrm{X}$ terlebih dahulu, berbuat atau tidak berbuat terhadap norma- norma sosial yang ada atau sedang dibentuk. Sebagai suatu entitas, nampaknya dimulaidari sini Menurut Gramsci (2013), sosialisasi dan pengertianpengertiansebagai langkah awal menuju apa yang kita 
inginkan. Tentu tidak bisa dilakukan secara sendirian dan tidak bisa dilakukan dengan hanya sebulan dua tetapi harus dilakukan berbulan-buan dan mungkin juga bisa bertahun-tahun. Merubah suatu kondisi lama dengan yang baru, seyogyanya tidak dipertimbangkan mengenai waktu. Lebihlebih lokasi mereka dekat dengan pusat kota, mungkin makin sulit untuk dhimbau atau dikatakan. Banyak kasus yang terjadi, mereka punya cara-cara tersendiri untuk tidak-sepaham. Inilah yang serba menyulitkan. Mereka kelihatan mengikuti permintaan atau himbauan kita pada hari itu tetapi tidak mengerjakannya pada hari berikutnya.

\section{DAFTAR PUSTAKA}

Gramsci, Antonio, 2013. Prison Notebooks; Catatan-catatan dari Penjara. Pustaka Pelajar. Yogyakarta.

Martono, Nanang, 2016. Sosiologi Perubahan Sosial. PT. RajaGrafindo Persada. Jakarta.

Ritzer, George dan Barry Smart, 2012. Handbook; Teori Sosial. Nusa Media Bandung dan Dadit Media. Jakarta.

Ritzer, George, 2012. Teori Sosiologi. Pustaka Pelajar. Yogyakarta.
Scott, John, 2012. Teori Sosial; Masalahmasalah Dalam Sosiologi. Pustaka Pelajar. Yogyakarta.

\section{Internet}

http://www.casageek.com.br/en/wallplate-geek-nerd/484-wall-platedanger-zombie-area.html [Akses, 19 Agustus 2019]

Kompas.com, Rabu (29/3/2017) 